\title{
The Postcolonial Bare Life: Reflections on Agamben and the Coronavirus
}

\author{
Vincent Pacheco \\ University of Macau. ORCID id: oooo-0oo2-1812-5528. \\ Email: vincent.pacheco@connect.um.edu.mo
}

\begin{abstract}
The ongoing pandemic has undeniably propagated an atmosphere of paranoia and discontent in both the West and the East, and it is in this context where Giorgio Agamben wrote a brief but controversial article where he argues that this pandemic enables governments to opportunistically decree a state of exception that will lead to tyranny. Critics have generally responded negatively to Agamben's views, given that this is not the case in the West. It is becoming apparent, however, that the very thing Agamben feared is happening in post-colonial states. In this paper, I look at how the current pandemic enables a postcolonial state like the Philippines to define (or redefine) the notion of life through authoritarian measures as it claims a strong democratic mandate. My reflections on Agamben takes off from Rodrigo Duterte's national speeches during the pandemic. I aim to show that his manifestly militarized response is a manifestation of the sovereign exception that politicizes and separates zoe (which is mere biological life) from bios (which is livable life that can participate politically), as Agamben might put it. Finally, I offer reflections on how the postcolonial legacy of the Philippines could potentially complicate how we might think about the notion of bare life-a figure that is neither zoē nor bios.
\end{abstract}

Keywords: Giorgio Agamben, Rodrigo Duterte, Populism, Coronavirus, Bare Life.

On February 26, 2020, Giorgio Agamben (2020a) wrote a controversial article on Quibolet titled "The Invention of the Epidemic" in response to the virus. He argues that the ". . alleged epidemic of coronavirus" can potentially enable governments to define a certain "state of exception" that will lead to government tyranny and that "... the limitations of freedom imposed by governments are accepted in the name of a desire for safety that was created by the same governments that are now intervening to satisfy it (Agamben, 2020a). What makes the article controversial is that Agamben (2020a) basically suggests that the state is so sinister that it basically exaggerated (or as Agamben's puts it "invented") the pandemic so that it can expand government authority over its constituent populations. Agamben's (2020a) article drew negative reactions from critics and academics alike. Agamben's (2020b) primary fear is that the coronavirus epidemic can potentially lead to a "permanent state of emergency" as he writes that our society, having sacrificed freedom for the sake of so-called "security concerns," has condemned itself to a perennial state of insecurity and fear. While Agamben (1998) was writing his reflections on the coronavirus in the Western context (mainly on how Italy handled the crisis), it is important to note that the very thing he feared in Homo Sacer: Sovereign Power and Bare Life and his succeeding works is happening in both western states and postcolonial states such as Poland Hungary, Brazil, Rwanda, and the Philippines. The heads of state of these countries have arguably used the coronavirus as a

(C) AesthetixMS 2020. This Open Access article is published under a Creative Commons Attribution Non-Commercial 4.0 International License (http://creativecommons.org/licenses/by-nc/4.o/), which permits non-commercial re-use, distribution, and reproduction in any medium, provided the original work is properly cited. For citation use the DOI. For commercial re-use, please contact editor@rupkatha.com. 
pretext to expand government authority through emergency powers (which, as Agamben (2005) might put it, involves states (re)defining what the "state of exception" is).

Given this broad context in mind, it might be more fruitful to look at a more specific case instead of giving general reflections on Agamben and the pandemic. What I want to look at is the socio-political context of the Philippines, where President Rodrigo Duterte, endearingly called "Tatay Digong" or "Father Digong" by his supporters, is still continuing his supposedly valiant crusade (as his supporters might put it) against all the supposed drug addicts of the country despite the fact that there is an ongoing pandemic. The Philippines currently has the highest cases of Covid-19 in South East Asia (Esguerra, 2020). From early March, Duterte has been giving national speeches (usually late at night) addressed to the people. It is in these speeches where Duterte offers varied responses to the pandemic such as a military enforced lockdown and quarantine measures, an emergency subsidy program, threats of martial law, and various tirades against the communists. My reflections on the value of Giorgio Agamben's thoughts takes off from these national speeches as I look at how the current pandemic shows how the Philippine government defines (or redefines) the notion of life through extraordinary measures that are borderline "authoritarian". I also look at the anti-terror bill that was recently passed by the Philippine government. The provisions of this law give a vague definition on what counts as "terrorism", and this can potentially allow the state to abuse its power. Or, as Agamben might put it, the Anti-Terror law, as a manifestation of the sovereign exception, further politicizes and separates zoē from bios to exert more power over the populace. With the unforgiving pandemic and the iron-fist state placing the archipelago in a state of uncertainty, the grim and sinister condition of the country unfortunately affirms Agamben's fears that the pandemic has allowed people to accept (and even yearn for) these draconian measures "that they don't seem to notice that their life has been reduced to a purely biological condition" (2020b). Towards the end of this paper, I offer reflections on how the postcolonial legacy of the Philippines could potentially complicate how we might think about the notion of bare life-a figure that is neither zoe nor bios.

\section{Giorgio Agamben's Bare Life and the State of Exception}

Giorgio Agamben starts to theorize the nature of sovereign power through his concepts of Homo Sacer and Bare Life in his arguably best-known work- Homo Sacer: Sovereign Power and Bare Life. He uses the Greek notions of Zoē, which refers to mere biological life, and Bios, which refers to biological life that can participate politically, to elaborate on his account of the Homo Sacer (Agamben 1998, pp. 1-3) - "life that may be killed but not sacrificed" (Agamben, 1998, p. 82). Agamben argues that the state draws its sovereign power from its ability to define what constitutes Zoē and Bios, and the result of which is the politicized Zoe or bare life (1998, p. 83). This practice of sovereign exception allows states to make a distinction between those that may live good lives and those who must live bare lives (Agamben, 1998, pp. 83-85). This distinction is necessary for the sovereign state to systematically exert power on populations (Agamben, 1998, p. 131). In State of Exception (2005), Agamben further expands and theorizes on Carl Schmitt's ideas on state power. Agamben (2005) notes here that "the sovereign power. . is essentially grounded in the emergency linked to a state of war" and that "the metaphor of war becomes an integral part of the presidential political vocabulary whenever decisions considered to be of vital importance are being imposed" (p. 21). This "metaphor of war" is evident in Duterte's speeches during the pandemic and situating the pandemic as an enemy of the state provides a justification for the "sovereign" (and in this case, Duterte) to enact extraordinary measures. Agamben (2005) further writes that: 
Indeed, the state of exception has today reached its maximum worldwide deployment. The normative aspect of law can thus be obliterated and contradicted with impunity by a governmental violence that-while ignoring international law externally and producing a permanent state of exception internally-nevertheless still claims to be applying the law. (p. 87)

Interestingly, Agamben says this nearly two decades before the pandemic and to further this thought, I note in this paper that the state of exception has not yet reached its apex during that time, rather, the current situation worldwide might be indicative of the state of exception's "maximum deployment" and perhaps, there is more to come in the coming months as we deal with the socio-economic ramifications of the virus. Another point is that Rodrigo Duterte's supposed sinister state is not only justified by the current war against the virus, but is also partly justified by Duterte's anti-colonial stances as he repeatedly throws tirades against Western institutions that attempt to hold him accountable for various human rights abuses.

\section{Reflections on President Duterte's late night talks}

With the increase of confirmed Covid-19 cases in the Philippines, Rodrigo Duterte signed the "Proclamation no. 922" on March 9, 2020, which placed the Philippines under a "State of Public Health Emergency". Days after this, in a late-night address to the Philippines on March 12, 2020, Duterte, with his cabinet members and his top military officers in the background, announced that he will place Metro Manila (the capital region of the Philippines) under "community quarantine", which is basically a lockdown. In an excerpt from the same address: Duterte says:

If you try to fight [against figures of authority], it becomes---you might---punch or what then it becomes an assault on an agent of a person in authority. In which case, from a simple violation of a rule, it will now ripen into a crime that is punishable by law and you can go to prison. That's the problem. I don't want. I don't want. I don't want the military and the police to confront you [referring to those who violate the quarantine measures] ${ }^{\mathrm{i}}$ (Duterte, March 12, 2020-Public Address Transcript)

In a sharp contrast to how other nations handled the pandemic, Rodrigo Duterte invokes the metaphors of war here as he indicates his willingness to use the military and the police alongside health workers to deal with the pandemic. Duterte however attempts to assure the public by saying:

There is no struggle of power here. There is no conflict here. There is no war. It's just a matter of protecting and defending you from COVID-19. That's about it. It has nothing to do with the power of the military or the power of the police, nor or my power and of these guys beside me. (Duterte, March 12, 2020-Public Address Transcript) ${ }^{\mathrm{ii}}$

It is interesting that while Duterte attempts to assure the public that there will be no abuse of state power, he lays bare the full potentiality of his power (and the government) over the citizens in that very excerpt. True enough, for the duration of the lockdown, the government mandated military and the police have employed draconian measures reminiscent of martial law measures supposedly in the name of "public health". From March 17, 2020 to May 31, 2020, the police have arrested a total of 57,177 for quarantine violations (Buan, 2020) and in that same time period, the military deployed 2,500 soldiers in the capital region (Gotinga, 2020a). Duterte even gives a "shoot to kill" order saying "My orders are to the police and military, also the barangay, that if there is trouble or the situation arises that people fight and your lives are on the line, shoot them dead." 
(Amnesty International, 2020) This is eerily reminiscent of Achille Mbembe's "Necropolitics" in which ". . .the ultimate expression of sovereignty resides. . .in the power and the capacity to dictate who may live and who must die" (2003, p. 11) and statements like these have effectively reduced the populace to mere biological life with the continued support of the people.

Despite these extreme measures and the fact that the Philippines has the longest lockdown period in the world, it arguably did little to stem the tide of covid-19. As of August 16, 2020, the country's confirmed number of cases is 157,918 with a death toll of 2,600 (Gotinga, 2020b). What has Duterte accomplished then? In the midst of a pandemic, the Philippine Congress (who is allied to Duterte) refused to give a "broadcast franchise" to ABS-CBN, the largest television network in the country. International and domestic observers say that this refusal is politically motivated and that this is an attack on "press freedom"-which one of the main pillars of a democratic state (Aspinwall, 2020). Duterte has also vowed to continue his violent war on Drugs back in June 2020 which has already claimed around 6000-2700o lives ${ }^{\mathrm{iii}}$ (Lema, 2020). Through Congress, Duterte was able to pass the controversial Anti-Terrorism Act of 2020 on July 3, 2020, which in its current state, can potentially allow the state to brand any Filipino citizen as "a terrorist" and it renders the "Writ of Habeas corpus" useless, as this allows the Philippine government to conduct warrantless arrests.

\section{The Anti-Terror Law as the State of Exception made into the rule}

The "Anti-Terrorism Act of 2020" includes a provision that creates an Anti-Terrorism Council or ATC for short. The ATC is made up of 9 members, most of which are cabinet members. The law also designates the National Intelligence Coordinating Agency (which is roughly the Philippine equivalent of the CIA or MI6) as the "Secretariat of the ATC" or basically the executor of the aforementioned law (Anti-Terrorism Act of 2020, 2020). What is alarming about this law is that it defines acts of terrorism as:

Engaging in acts intended to cause death or serious bodily injury to any person or endangers a person's life;

Engaging in acts intended to cause extensive damage or destruction to a government or public facility, public place, or private property;

Engaging in acts intended to cause extensive interference with, damage, or destruction to critical infrastructure;

Developing, manufacturing, possessing, acquiring, transporting, supplying, or using weapons; and

Releasing dangerous substances or causing fire, floods or explosions when the purpose is to intimidate the general public, create an atmosphere to spread a message of fear, provoke or influence by intimidation the government or any international organization, seriously destabilize or destroy the fundamental political, economic, or social structures in the country, or create a public emergency or seriously undermine public safety. (AntiTerrorism Act of 2020, 2020)

The vagueness of these stipulations allows the ATC to "designate" any individual and organization who are committing or attempting to commit the above stipulations as a "terrorist". The unprecedented powers given to the executive branch seems to confirm Agamben's fears that governments will use the virus as an opportunity to expand state power. As the law was passed in 
the middle of the pandemic, opposition groups (which are in the minority) are placed in a double bind: if they muster up and protest in the streets, they would be vectors that will further enable the pandemic; if they do nothing of the sort, then the lack of mass action would be interpreted by the government as mass approval by the public. The provisions of the law which are resonant of laws in effect only in times of war has become the rule in a country where the number of "terrorists" are relatively miniscule. ${ }^{\text {iv }}$ This law allows Duterte to arbitrarily inflate the number of terrorists, which in effect, will justify the very law that supposedly aims to prevent terrorism. It is evident here that Agamben's theory is made into reality as this law allows the government to produce bare lives, by blurring the distinctions between zoe and bios, so much so that it is increasingly difficult to identify which is which. After all, the vagueness of the law is precisely where the sovereign draws strength from.

\section{Final Reflections on Agamben and the Postcolonial Bare Life}

In an interview with RT back on May 22, 2017, Duterte basically says that human rights is tool of imperialism saying that:

"My orders were very clear: go out and hunt for them, the drug lords. Arrest them if possible, but if you are confronted with the violence that could place your life, the policemen or the security in danger. Kill them. Because in the past that was what really prevented the police and the military from doing it. Why? Because they were so afraid of the human rights thing, which is a new phenomenon. It's actually the human rights in the guise of human rights. Countries like EU and America are interfering in the affairs of other nations, in the guise of human rights." (RT, 2017, 2:48 - 3:35)

In the last three years, Duterte has shrugged off criticism of his supposed violation of human rights. The EU, the US and the UN have enacted various resolutions and legislations that sanction the Philippine government for the War on Drugs. These measures did little to stop these human rights violations and it only served to fuel Duterte's anti-colonialist stance. Despite all these, Rodrigo Duterte still has the mandate of the people even as he is "the only elected president on the planet being investigated for crimes against humanity by the International Criminal Court in The Hague" (Bernstein 2020). It is indeed grim and dark when things that supposedly prevent the production of bare life are regarded as an act of western imperialism. While Agamben was proven wrong about the coronavirus in a lot of aspects, what is frightening is that he might be right (at least in the Philippine context) that the state is so sinister that it will use the virus to expand government control. After all, Agamben (2020c) notes in the "Reflections on the Plague" that "... proceeding from the fear of losing one's life can only result in tyranny, the monstrous Leviathan with his drawn sword".

\section{Endnotes}

' Italics indicate translated material from Filipino. Translation was done by the Author. Original transcript is:

Kung makipag-away ka, it becomes --- baka mag --- masuntok mo o ano then it becomes an assault on an agent of a person in authority. In which case, from a simple violation of a rule, it will now ripen into a crime 
that is punishable by law and you can go to prison. That's the problem. Ayaw ko. Ayaw ko. Ayaw ko na masita kayo ng military pati pulis.

ii Italics indicate translated material from Filipino. Translation was done by the Author. Original transcript is: For Manila, may... Ayaw namin gamitin "yan pero --- kasi takot kayo sabihin "lockdown". And a --- but it's a lockdown. There is no struggle of power here. Walang away dito, walang giyera. It's just a matter of protecting and defending you from COVID-19. That's about it. It has nothing to do with the power of the military or the power of the police, nor or my power and of these guys beside me

iii The reason for this huge discrepancy is that the government data is different from the data of the opposition and human rights groups. The government would peg the death toll at around 6ooo, while the Human Rights Watch gives a figure close to 27000. See https://www.hrw.org/world-report/2020/countrychapters/philippines\#2zace2

iv Current numbers of the New People's Army is currently around 40oo, which are spread throughout the Philippine archipelago. Other rebel/terrorist groups such as the Abu-Sayaff and Bangsamoro Islamic Freedom Fighters has only around 400 and 300 members, respectively.

\section{References}

Agamben, G. (1998). Homo Sacer: Sovereign Power and Bare Life. Translated by Daniel Heller-Roazen. Stanford: Stanford University Press.

Agamben, G. (2005). State of Exception. Translated by Kevin Atell. The University of Chicago Press.

Agamben, G. (2020a, February 26). The Invention of an Epidemic. European Journal of Psychoanalysis. Retrieved from https://www.journal-psychoanalysis.eu/coronavirus-and-philosophers/

Agamben, G. (202ob, March 17). Giorgio Agamben: “Clarifications”. An und für sich. Retrieved from https://itself.blog/2020/03/17/giorgio-agamben-clarifications/

Agamben, G. (2020c, March 27). "Reflections on the Plague". Medium. Retrieved from https://medium.com/@ddean3ooo/reflections-on-the-plague-giorgio-agambenb616763b6259\#: :text=They\%2oare\%2C\%2othus\%2C\%2oreflections\%2oon,even\%2oreligious\%2oan d\%2opolitical\%2obeliefs.

Amnesty International. (2020). Philippines: President Duterte gives "shoot to kill" order amid pandemic response. Amnesty International. Retrieved from https://www.amnesty.org/en/latest/news/2020/o4/philippines-president-duterte-shoot-to-killorder-pandemic/

Anti-Terrorism Act of 2020, Republic Act No. 11479 2020. Retrieved from https://www.officialgazette.gov.ph/downloads/2020/o6jun/20200703-RA-11479-RRD.pdf

Aspinwall, N. (2020, May 7) Fears of Press Freedom Crackdown After Philippines Orders Largest Broadcaster Off Air. The Diplomat, Retrieved from https://thediplomat.com/2020/05/fears-ofpress-freedom-crackdown-after-philippines-orders-largest-broadcaster-off-air/

Berg, A. (2020, March 23) Giorgio Agamben's Coronavirus Cluelessness. The Chronicle of Higher Education. Retrieved from https:/www.chronicle.com/article/giorgio-agambens-coronavirus-cluelessness/

Bernstein, R. (2020, February 22) The Paradox of Rodrigo Duterte. The Atlantic. Retrieved from https:/www.theatlantic.com/international/archive/2020/o2/philippines-rodrigo-dutertechina/606754/

Buan, L. (2020, June 1). 2,875 Filipinos still detained for violating quarantine. Rappler. Retrieved from https://rappler.com/nation/pnp-report-detained-filipinos-coronavirus-quarantine-violators-may31-2020 
7 | The Postcolonial Bare Life: Reflections on Agamben and the Coronavirus

Esguerra, D. J. (2020). PH now has most COVID-19 cases in Southeast Asia. Inquirer.net. Retrieved from https://globalnation.inquirer.net/190091/ph-now-has-most-covid-19-cases-in-southeast-asia.

Gotinga, J.C. (2020a, April 23). Even in stricter lockdown, military says it will play 'support role'. Rappler. Retrieved from https://rappler.com/nation/military-support-role-stricter-lockdown-coronavirus

Gotinga, J.C. (202ob, August 15). PH coronavirus deaths reach 2,60o. Rappler. Retrieved from https://rappler.com/nation/coronavirus-cases-philippines-august-15-2020

Lema, Karen. (2020). Philippines' Duterte renews threat to kill drug dealers after big bust. Retrieved from https://www.reuters.com/article/us-philippines-drugs/philippines-duterte-renews-threat-to-killdrug-dealers-after-big-bust-idUSKBN23 $\mathrm{CoE}_{3}$

Mbembe, Achilles. (2003). "Necropolitics." Public Culture 15 (1): 11-40.

Nancy, Jean-Luc. (2020). Viral Exception. European Journal of Psychoanalysis. Retrieved from

Proclamation No. 922. (2020). Retrieved from https://www.officialgazette.gov.ph/downloads/2020/o2feb/20200308-PROC-922-RRD-1.pdf

RT. (2017, May 22). “They want me to fight China. It's gonna be a massacre!' - Duterte to RT (FULL INTERVIEW)." [Video]. Youtube. https://www.youtube.com/watch?v=rHjlCmdyesY

Vincent Pacheco is currently taking up his M.A. in English Studies at the University of Macau. His primary research interests are critical theory, populism, and visual culture. 